\title{
Rural out-migration and return: perspectives on the role of the everyday reality and the idyll in Ireland
}

\author{
Mary Cawley
}

National University of Ireland Galway. Whitaker Institute for Innovation and Societal Change and School of Geography, Archaeology and Irish Studies mary.cawley@nuigalway.ie

\begin{abstract}
The aim of this article is to add to understandings of the rural idyll as an influence on return migration. Interviews were conducted with thirty-four first generation rural returnees in Ireland and their responses were analysed in depth. Unemployment and constraints on career and personal fulfilment influenced migration overseas, usually, to a major city. Consciousness of the loss of features of the idyll emerged in adapting to life in the destination area. Memories of the positive features of family and rural life influenced return, particularly for those with children, but the capacity to return was dependent for most on economic circumstances. Certain features of the idyll were recaptured on return but everyday rural reality intruded also. Some people migrated again. An improved understanding of the idyll and of the everyday reality should help to better inform policy to re-attract out-migrants back to the countryside.
\end{abstract}

Keywords: rural reality; idyll; return migration; Ireland

Resum. Emigració rural i retorn: perspectives sobre el paper de la realitat quotidiana i l'idil.li a Irlanda

El propòsit d'aquest article és reconèixer el paper de l'idil.li rural com un factor influent en la població emigrant retornada. S'han dut a terme entrevistes a trenta-quatre emigrants de primera generació retornats a Irlanda. La desocupació i les limitacions en el desenvolupament laboral i personal van afavorir l'emigració a altres països, normalment a ciutats importants. La consciència de la pèrdua de característiques pròpies de l'idil.li rural apareix en l'etapa d'adaptació a l'estil de vida de l'àrea de destinació. Els records de les característiques positives de la vida rural van afavorir el retorn dels emigrants, especialment els que tenien fills. La capacitat per al retorn depenia en tot cas de les circumstàncies econòmiques. 
Certes característiques de l'idil.li rural es van recuperar un cop retornats, però la realitat de la vida al camp es va fer també palesa. Algunes persones van emigrar de nou. Una millor comprensió de l'idil.li i de la realitat quotidiana ajudaria a dissenyar les polítiques necessàries per fomentar el retorn de les persones emigrades al medi rural.

Paraules clau: realitat rural; idil.li; migració de retorn; Irlanda

Resumen. La emigración rural y el retorno: perspectivas sobre el papel de la realidad cotidiana y el idilio en Irlanda

El propósito de este artículo es reconocer el papel del idilio rural como un factor influyente en la población emigrante retornada. Se han llevado a cabo entrevistas a treinta y cuatro emigrantes de primera generación retornados a Irlanda. El desempleo y las limitaciones en el desarrollo laboral y personal propiciaron la emigración a otros países, normalmente a ciudades importantes. La conciencia de la pérdida de características propias del idilio rural aparece en la etapa de adaptación al estilo de vida del área de destino. Los recuerdos de las características positivas de la vida rural favorecieron el retorno de los emigrantes, en especial de los que tenían hijos. La capacidad para el retorno dependía en todo caso de las circunstancias económicas. Ciertas características del idilio rural se recuperaron una vez retornados, pero la realidad de la vida en el campo se hizo también patente. Algunas personas emigraron de nuevo. Un mejor entendimiento del idilio y de la realidad cotidiana ayudaría a diseñar las políticas necesarias para fomentar la vuelta de las personas emigradas al entorno rural.

Palabras clave: realidad rural; idilio; migración de retorno; Irlanda

Résumé. Émigration rurale et retour: perspectives sur le rôle de la réalité quotidienne et de l'idylle en Irlande

Cette contribution est désignée à contribuer à une meilleure compréhension de l'influence de l'idylle rurale sur le retour des émigrés. Elle est basée sur l'analyse en détail des 34 entretiens avec des émigré(e)s qui sont rentré(e)s à la campagne en Irlande. L'émigration, normalement vers une ville à l'étranger, était influencée par le manque d'emploi et des contraintes dans le domaine professionnel et personnel. À l'étranger l'émigrant se souvient de la perte de l'idylle. Le retour est influencé par les souvenirs de la vie familiale et les attributions positives du rural, surtout parmi ceux/celles qui ont des enfants. La capacité de retour dépendait dans presque tous les cas des circonstances économiques. Après le retour, certains aspects de l'idylle ont été récupérés mais la réalité de la vie rurale apparaît aussi. Certaines de ces personnes ont décidé d'émigrer à nouveau. Une meilleure compréhension de l'idylle et de la réalité quotidienne pourrait contribuer aux politiques concues pour encourager le retour des émigrés dans les zones rurales.

Mots-clés: réalité rurale; idylle; migration de retour; Irlande

\section{Summary}

$\begin{aligned} \text { 1. Introduction } & \text { 5. Reasons for return } \\ \text { 2. Concepts } & \text { 6. Life after return } \\ \text { 3. Methodology and sample } & \text { 7. Conclusions } \\ \text { characteristics } & \text { Acknowledgements } \\ \text { 4. Migration and life overseas } & \text { Bibliographical references }\end{aligned}$




\section{Introduction}

Out-migration of young working age people is frequently a feature of rural areas located at substantial distances from centres of economic activity and employment (Jentch and Shucksmith, 2004; OECD, 2010). For many of them the countryside is a place of harsh reality characterised by limited economic opportunities, poor service facilities and restrictions on personal development. At the same time, idyllic imaginary qualities are associated with the countryside in general and with particular areas of countryside and can serve to attract new residents and second home owners (Halfacree, 1993, 2012). Idyllic features of the rural for former out-migrants are less well understood. This paper explores the role of an idyllic imaginary, in contrast with the daily reality, in attracting out-migrants back to live in the countryside. In its poetic origins, in third-century Greece, the idyll lauded pastoral life in contrast with emerging urbanisation (Williams, 1973). Since the late nineteenth century, conceptualisation of the idyll has come to incorporate tropes of family and community, as well as pastoral landscapes, reflecting the influence of German sociologist Ferdinand Tönnies (1887/1963) in distinguishing between a gemeinschaft rural communal society in contrast with a more urban-based associational gesellschaft. The everyday rural reality for the resident populations is often counter-idyllic (Cloke, 2003). A process of secular decline may be long-established which the arrival of new migrants does not necessarily reverse (Jentch and Shucksmith, 2004). In this context, the return of former outmigrants, whether working or retired, often brings greater benefits in terms of skills, experience, investment and support of local services (Dustmann et al., 2011). A remembered idyll is known to influence return (Ní Laoire, 2007; Farrell et al., 2012; Haartsen and Thissen, 2014; Cawley and Galvin, 2016; Morse, 2017). However, the idyll's presence in the memories of places of origin among economic out-migrants and its role in attracting them back has received much less attention than its influence in attracting new in-migrants to the countryside, as part of counterurbanisation processes, and deserves further attention (Haartsen and Thissen, 2014; Morse and Mudgett, 2017).

This paper aims to contribute to understandings of the idyll as an influence on migrant return using evidence for rural Ireland which has a long history of out-migration. It does so with reference to a sample of international migrants (emigrants) who left and returned to places with less than 1500 population ('aggregate rural areas' in the Irish census), usually the same place. The respondents were asked to reflect on their reasons for departure, their experiences of living in cities overseas, their motivations for returning and their experiences following return. References to what may be described as idyllic features of rural life emerged unprompted from many of the narratives which were interlinked with stage in the life-course. Tensions emerged also with daily reality on return, both for those who held an idyllic imaginary and for those who did not. Policy makers need to be more aware of the different expectations and experiences of different groups of returnees. 


\section{Concepts}

The loss of young working age people through migration to larger places is well recognised in rural areas that are distant geographically and economically from the main centres of economic activity (Jentch and Shucksmith, 2004; Haartsen and Thissen, 2014). Access to higher education also often involves migration from a rural area of origin (Thissen et al., 2010). In the Irish case, labour migration to cities within the state and internationally is long-established (MacLaughlin, 1994). A pattern of path-dependency is often at work where out-migrants follow established flows using links with relatives and friends in overseas cities (Walter, 1980). There are many reasons for continued out-migration among rural working age people. Farm incomes and agricultural employment continue to decline because of increased mechanisation and competition from imports in an increasingly globalised economy (Ploeg, 2012). Non-agricultural employment is often limited and advanced communications infrastructure, which has potential to create new opportunities for rural economic enterprise, usually lags behind that in urban centres (Shucksmith, 2018). Seasonality may act as a constraint on tourism as a source of permanent employment in scenic areas (Schmallegger and Carson, 2010). An idyllic vision of low density settlement amid green fields can be accompanied by low levels of public transport provision and poor accessibility to essential services (OECD, 2010). These features impact across the socio-economic spectrum stimulating out-migration. As well as being 'pushed' in this way, opportunities in an external destination can exert a 'pull' on the potential migrant, although the relationships between these factors are complex (Castles et al., 2014: 28). The desire to attain self-actualization through contact with more liberal attitudes and lifestyles and access to a wider range of social and economic experiences than are present in a rural area of origin is recognised also as being part of the attraction of the urban (Arnett, 2000). The rural out-migrant imaginary is likely to be a counter-idyllic one.

The role of an idyllic imaginary has received extensive attention in literature relating to counterurbanisation in which new migrants to the countryside dominate (e.g., Boyle and Halfacree, 1998; Halfacree, 2012). Recognised tropes include open landscapes, fresh air, benefits of a countryside environment for children, low levels of crime and a perceived sense of community, some of which are recognised as being highly problematic (Matthews et al., 2000; Cloke, 2003; Rye, 2006; Woods, 2011; Christiaanse and Haartsen, 2017; McHugh-Power et al., 2017). By comparison with documentation of the quest for an idyll by newcomers, its influence on return migration has received relatively less attention, although elements of an idyll are known to influence return to a place of origin (e.g. Ní Laoire, 2007; Haartsen and Thissen, 2014; Morse and Mudgett, 2017). The evidence suggests that the imaginary is imbricated with links to family and place and may change over the life-course. Ní Laoire's research (2007: 332) among a group of thirty returnees to rural Ireland pointed to inter-relationships between "classic counterurbanisation discourses" and 
notions of family and kinship. Morse and Mudgett's (2017) respondents in rural Vermont in the United States of America (USA) reported homesickness and a longing for landscape as reasons for return. Haartsen and Thissen's (2014) research among young returnees in the Netherlands identified three inter-linked dimensions of relations between self, others and environment, following Gustafson (2001a: 9). Gustafson (2001b: 650) uses the metaphor of 'roots' to signify such "emotional bonds with the physical environment (which) often also contain notions of local community, shared culture, and so forth", associations described by Pascual-de-Sans (2004) as ideotopes. Motivations for return among returnees in rural Northern Ireland included childhood memories, life-course stage, lifetime experiences and future life-course expectations, in which a rural idyll may feature (Stockdale et al., 2013). The negative influences of anonymity and absence of a feeling of belonging, in a migration destination, may also influence a quest to recapture the familiarity of home (Relph, 1976; Hay, 1998; Ahmed, 1999). Thus, migration may signify freedom, opportunities and new experiences but can be associated with uprootedness and the perceived loss of previously meaningful places (Relph, 1976; Fielding, 1992). This article seeks to add to the literature by exploring the proposition, among first generation returnees, that counter-idyllic elements which propel out-migration and idyllic elements may be present in the imaginaries of out-migrants and returnees to varying extents and that one may over-ride the other at particular points in time.

An idyllic imaginary, however conceived, is not sufficient to attract international emigrants back to rural areas. Economic resources in the form of employment, investment capital to permit a business to be established, inheritance of a property or business or transferrable pension benefits, among retirees, are usually required. Nevertheless, positive recollections of a rural childhood and continued transnational contacts with family and friends, through various media of communication and return visits, are known to be influential (Conway and Potter, 2006; Barcus and Brunn, 2010). Return can permit certain aspects of a remembered idyll to be attained, but re-establishment in an area of origin, as long-recognised, can be problematic (Gmelch, 1980). The physical place may differ from when the migrant left, social relationships may need to be re-negotiated and service facilities are likely to compare unfavourably with those in a large overseas city (Gustafson, 2001a; Barrett and Mosca, 2013). Tensions may therefore be present.

\section{Methodology and sample characteristics}

The reported study is based on a convenience sample of thirty-four returned migrants, who were interviewed in 2014 by university geography students, usually a family member of the interviewee, using a schedule prepared by the author and following recognised protocols (Drooglever Fortuijn and van der Meer, 2006). Statistical representativeness was not sought. Following an ethnographic methodology, the study sought instead to capture a range of 
experiences of migration and return over time and, thereby, contribute to greater understanding of the phenomenon. The interviewee was required to have migrated from the Republic of Ireland (RoI) as an adult, lived overseas for one year or more, and returned either permanently or for one year or more before re-migrating (and, possibly, returning again). The definition of migration is long-established and currently used by Eurostat (2018). All left from and returned to a place of less than 1500 population, usually the same place, permitting the migrant to compare recollections of that place whilst absent with the reality on return.

The interview schedule included closed questions profiling the social and economic attributes of the interviewee at the various migration stages. Transnational contacts with home were queried with reference to the methods used. The fora where contact took place with Irish people in the destination area(s) were recorded. Opportunities were provided in open questions to report (in the respondent's perceived order of priority) the influences on migration, experiences overseas, the reasons for return and experiences associated with rural residence again. The presence of an idyllic imaginary, which involved proximity to family and friends in a rural setting, emerged unprompted from the narratives. The data were entered in Excel and the qualitative statements were analysed in an iterative way to identify key themes and sub-themes (Saldăna, 2013). Detailed insights emerged relating to varying periods of absence from the early 1950s until recently. Most returned from a major city.

The sample comprises twenty-four males and ten females, an imbalance among returnees that contrasts with the traditional national RoI pattern (Punch and Finneran, 1999). This imbalance arises, in part, from higher levels of international, rural male, emigration (and later return) during the recessionary years of 2008-2010. Also, some rural female emigrants were excluded from the analysis because of returning to larger centres of population. The average period of time spent overseas was 6.4 years with a maximum of 30 years, a minimum of 1 year and a mode of 2 years. Absences of one or two years were reported in particular by migrants on short-term work permits in Australia. The majority left in their late teens and early twenties when freedom to move is greatest (Rogers et al., 1978). Twenty-eight respondents reported their marital/ conjugal status as being 'single' at migration, five had a spouse or partner and one migrant had a spouse and children. Most had at least a secondary level (high school) education and over one-third of both males and females held a third-level qualification (Table 1). Four males, who completed their education before free access to secondary schooling became available (in 1967), held a primary education only. Unemployment and under-employment were high: some $65 \%$ overall, including more males than females, were unemployed or under-employed, especially during the economic recession of 2008-2010. Employment in an occupation below the qualification level was particularly marked among those with a third-level qualification. More generally, unemployment was widespread among professionals, skilled and unskilled workers in the construction industry. Female nurses and a newly-qualified teacher were 
Table 1. Education and employment at migration $(n=34)$

\begin{tabular}{lc}
\hline Education completed & Number and (\%) \\
\hline Primary & $4(11.8 \%)$ \\
Secondary & $13(38.2 \%)$ \\
Third-level & $13(38.2 \%)$ \\
Non-graduate, post-secondary & $4(11.8 \%)$ \\
\hline Employment & Number and (\%) \\
\hline Employed & $11(32.4 \%)$ \\
Unemployed/under-employed & $22(64.7 \%)$ \\
Student & $1(2.9 \%)$ \\
\hline
\end{tabular}

Source: Return migrant survey.

unable to find employment in their professions also. In order to maintain confidentiality, the respondents are referred to by a number and specific locations are not named (e.g. rural\#1).

\section{Migration and life overseas}

Most respondents reported several reasons for migrating in order of importance. Personal factors (and supporting family in one case), such as finding employment or better employment, were ranked first by all occupational groups, following Sjaastad (1962). Linked aspirations to gain experience/ skills and improve longer-term employment prospects were cited by both males and females over time. A 21 -year-old male civil engineer who migrated to London, in 2010, because of "no available jobs, no income, wishing to gain experience and to experience travel" (rural\#14), echoed a qualified nurse who migrated, age 22 in 1985, to work in a London hospital, because of being "unemployed, to gain experience in the workforce and to experience living in another country" (rural\#31). Individualism in seeking freedom and adventure featured (Thissen et al., 2010), especially for recent long-distance migrants to Australia. A graduate, employed as a barman, who migrated to Sydney in 2011 for one year and worked in construction, reported that he sought "adventure", his "friends had migrated", he sought "a more lucrative income" and he was "bored with home life" (rural\#21).

The main destinations were major international cities with established Irish communities (notably, the Greater London Area [GLA], Perth, Sydney, New York and San Francisco in order of importance), reflecting path-dependency (Walter, 1980). Reciprocal labour market access for British and Irish citizens helps to explain a dominance of British destinations. Short-term work permits in engineering and certain skilled trades were available in Australia, in the late 2000s, and some recent graduates combined travel with work (Glynn et al., 2013). The sample respondents were legally resident in the USA. 'Strong ties' with family and friends were used by many skilled and unskilled migrants in 
finding employment in the Britain and even in Australia and the USA (Granovetter, 1973). Graduates and longer-distant migrants to Australia usually found employment through the 'weaker ties' of agencies and job advertisements. Regular contact with Irish people at work and socially in pubs, playing Gaelic games and attending matches was the norm and a potential source of social and psychological support.

Migration acted as an 'escalator' from under-employment and unemployment to work that aligned more closely with the qualifications held (Newbold, 2001). Additional formal qualifications were gained: for example, a degree in civil engineering, a nursing qualification, various certificates and diplomas, specialised driving licences and training in trades. Valuable experience was gained also in the vocational area, even during a year's contract, as described by the nurse mentioned above: "Definitely get more responsibility in work leading to better chances of promotion, more professional qualifications" (rural\#31).

Positive comparisons were made by both men and women with the area of origin, in terms of the wider range of shops, goods, prices and transport available in the destination. More diverse lifestyle options became accessible. An under-employed typing teacher who moved to the GLA in 1998 and became a secretary said: "There were so many amenities close at hand, within walking distance. There was always somewhere to go every night of the week, cinema, theatre, clubs, etc. Buses/trains were so plentiful" (rural\#16). Returnees from Australia valued the superior weather conditions and the outdoor lifestyle.

Moving from a rural area or small town to a large city required personal adaptation in ways that suggest disruption. Contrasts with the area of origin were recalled in references to the physical scale of the destination area and longer travel distances to work. The larger and ethnically diverse populations represented a major change for migrants in the 1980s. A female shop assistant who moved to the GLA, age 21 in 1986, said that "There was a far more diverse population in England ... in (place of origin) everyone was Irish, mainly from (place of origin)" (rural\#17). A 25 year old builder, who migrated to San Francisco in 1988, from a small town, commented that "America was more urbanised, modern and people (were) very different" (rural\#26). There were regrets for the countryside in expressions such as "missing the countryside", "life was much simpler in the countryside in Ireland" and missing a slower pace of life in comparison with the "faster pace of life" in a city. A sense of anomie was reported also (Ahmed, 1999), as described by the secretary above, who valued all of the material advantages of city life: "It was hard to get used to being anonymous in London, no one knew you, cared about you or where you were going/doing/wearing etc. No one even said 'hello', so it was a bit daunting but you get used to it and soon stop eye contact with people and avoid saying 'hello"' (rural\#16). Respondents who migrated at various periods of time to different cities referred also to missing family and friends and feeling homesick. A woman who worked in an Irish bank in the GLA had difficulty in having her accent understood initially (rural\#2). There was therefore a sense of loss of being part of a familiar social field (Gustafson, 2001a). 
All respondents maintained transnational contact with family and friends in Ireland through media which changed over time from letters to telephone, email, Skype and social networking sites, illustrating the 'elasticity of place' (Barcus and Brunn, 2010). Twenty-two migrants visited at least once annually. Short-term migrants in Australia and New Zealand did not visit whilst away but maintained regular contact.

\section{Reasons for return}

Features of an idyllic countryside, involving membership of a social field and perceived environmental qualities that contrasted with those of a city, together with the availability of employment, dominated the reasons for return, following Gustafson (2001a). Only one respondent referred to establishing a small business (as a carpenter) and he migrated later to work on a more lucrative project; entrepreneurship was therefore limited among the sample, although noted in some other Irish research (Cawley, 2015). Proximity to family and friends was ranked first by many males and females over time, followed by access to employment. For those with children, proximity to family may have been linked to anticipation of support with childcare, although this was not mentioned specifically. Younger returnees were most likely to rank the availability of employment in first place.

Whilst access to employment facilitated return, the motivations for return were inter-linked with life-course stage, in terms of expecting the birth of a child, planning a family, concerns about the welfare of children and retirement, and were often related to coming 'home' or establishing a 'home' in Ireland, as noted by Ní Laoire (2007). Fourteen migrants returned with a spouse/partner and a child or children whose welfare they cited. The female bank employee above returned with her spouse to her small town, in 2002, when work was available, because she "was pregnant, wanted child to be born and raised in Ireland and missed home" (rural\#2). The trope of establishing a 'home' and family in Ireland was an aspiration also for a 25-year-old engineer who spent two years in Perth and returned with his partner, in 2012, to "settle back home in Ireland", "find work, marry and start a family" (rural\#23). Welfare of children was framed with reference to features of an idyllic countryside being "a better lifestyle for them" than a city, as expressed by a construction worker who returned in 1996 after thirteen years in Britain (rural\#11). Lack of safety in a city was referred to. Recapturing features of rurality was present as a motivation in references to missing country life.

Family responsibilities to care for ageing or ill parents and personal difficulties influenced return in different decades, at times when employment was not necessarily easily accessible in Ireland. A young man returned earlier than expected, in 1959, when the Irish economy was underdeveloped, after five years working as a delivery man in London, to care for his dying mother and help his father on the farm. His experience of life in London related to the positive features of a regular income; recollections of the Irish countryside 
did not feature (rural\#13). A 22-year-old carpenter returned after one year in Sydney, in 2012, to part-time employment, because of parental illness and his own homesickness. He had close contact with Irish people and appreciated: "(the) higher wages, more to do socially, greater sense of optimism in Australia, fast-paced lifestyle". He missed playing Gaelic sports but did not refer to missing other aspects of life in the countryside, although these may have been inherent in his homesickness (rural\#21).

Other young people returned after brief periods of absence on obtaining employment in their home area. Their recollections of the area of origin when overseas related more to the absence of employment or appropriate employment than positive features of country life. They include a male teacher who returned from Italy with his Italian wife, in 2011, where he had enjoyed living, on obtaining employment and because of owning a house in Ireland, which saved on rent in Italy (rural\#1). A 24-year-old man spent a year working in Australia and travelling in South East Asia and returned on the expiry of a visa, in 2013, to return to college and did not report any sense of loss of an idyll whilst away (rural\#32). A 23-year-old skilled worker who found employment in Perth for a year and returned to employment, in 2008, enjoyed the climate and culture in Australia and made no reference to missing rural Ireland (rural\#33).

Remembered idyllic features of proximity to family and membership of a familiar social field exerted an influence, in particular, on the return of emigrants with children or planning a family, who were able to find employment in the area of return. In other cases, usually among single people in their twenties, when obligations to parents, the termination of a work permit and the availability of employment were instrumental in their return, an idyllic imaginary was absent in the reasons cited. The shorter periods of absence, when the more negative features that led to emigration may have been recollected more clearly, together with the foreshortening of the potential to gain the experience and self-fulfilment sought, seemed to override any idyllic recollections of the countryside of origin.

\section{Life after return}

The experience following return was queried in terms of: (i) perceived differences (changes) in the area of origin, (ii) the features enjoyed most, and (iii) any difficulties experienced. The differences arose primarily from changes in the Irish economy: especially, improved employment and housing developments during the 1997-2007 years of growth and unemployment and emigration of friends during the recession of 2008-2011. Increased ethnic diversity was noted, associated with international immigration from the late 1990s. The bank employee who returned with her spouse, in 2002, because of wishing her child to be born in Ireland, appreciated "being home and catching up with friends" but the physical and social environment had changed: "(place) had grown, massive housing developments around what was once a small village. More nationalities had arrived in Ireland" (rural\#2). These differences between 
expectations and experience point to the tensions that exist between the recollected idyll and a changed reality.

The features enjoyed most on return and the difficulties experienced also revealed tensions between motivations and the experience of living in the countryside again. Thus, the attainment of the idyll by those who sought it, or appreciated (or not) by those whose return was motivated by other factors, may be identified. The features enjoyed most by returnees highlighted relations with others and being part of a wider social field, irrespective of the period of absence, pointing to the endurance of social relationships over time. Reuniting with family and friends and being known, primary reasons for return, were also most enjoyed: "familiarity of home", "being closer to loved ones", "feeling at home".

Features of rural life that were missed when overseas were recaptured by many on return, in terms of "a more relaxed atmosphere", "a slower pace of life" and "peace and quiet". However, many of those who sought the perceived advantages of rural life for their children, as opposed to a city life, reported tensions arising from other aspects of rurality. A newly-qualified teacher who moved to London to gain employment in 1989 and returned in 2001, with her spouse and children, to provide the latter with a better lifestyle, appreciated: "Space- less densely populated; cleaner and greener- less graffiti, better air quality; food tasted better; less danger". Nevertheless, she found that "anything official or bureaucratic often took longer than expected" (rural\#25). A nurse who returned from London with her family, after seventeen years' absence, in 1990, to raise their children and "settle down" and "to be near to family and friends", found that the countryside was: "Too quiet and basic, the children found it very difficult to find things to do" (rural\#3). The construction worker, who returned with his family in 1996, after thirteen years in Britain, to provide "a better lifestyle" for his children adverted to "The nosiness of people" and his wife missing her family and friends whom she left behind (rural\#11). Low levels of basic retail and transport services were restrictive for many in the countryside. In the words of a secretary, who cited schooling and a better environment for their children as influential in the family returning from the GLA, there were: "Less shops, therefore less choice and value for money, as there was less competition" (rural\#27). A skilled tradesman who gained a degree in civil engineering whilst living in New York, and returned with his spouse and children, in 1991, because of having a house in Ireland, the growing economy and preferring "to raise kids in the country rather than the city", said that "the slower pace of life got taking used to again" (rural\#8). Unlike Morse and Mudgett's (2017) respondents in Vermont, specific landscape features were not cited as reasons for return, except by an early retiree who referred to the contrasts between a Scottish industrial city where he lived and his home area. He returned to make a better life for his son and to return 'home'. After twenty-seven years' absence, he enjoyed "walking on the beach and day trips to (my) island home" which was then unpopulated. He did not experience any problems associated with returning (rural\#12). 
Other respondents who, usually, had been absent for shorter periods of time and prioritised access to employment in an improved economy as a motivation for return, also valued renewed contact with family and friends. In general, broader features of an idyllic countryside received less attention from them. They reported difficulties in finding suitable employment, reduced incomes, poor rural services, loss of friendships and loss of independence. Thus, the teacher who returned to employment with his Italian wife, in 2011, enjoyed reuniting with his family but regretted leaving friends made abroad, had a reduced income and found that many of his friends had emigrated (rural\#1). The nurse, referred to earlier, who returned at the end of a one-year contract in 1986 to take up training as a midwife, moved in with her parents and saved money, but she referred to a "loss of privacy/anonymity - 'nosey' neighbour syndrome!". The lack of public transport was also a constraint on her social life (rural\#31). Loss of friendships made overseas echoes Ralph's (2014) findings for Irish returnees from the USA. Returnees from Australia missed the pleasant climate and the associated lifestyle.

Features of a remembered idyllic countryside were recaptured by returnees with children in particular who had been absent for periods of ten years or more. They experienced tensions on return, notably relating to deficiencies in service provision. Many of this group adapted, as De Bree et al. (2010) and Ralph (2014) noted elsewhere. Others migrated again to support their families. An air traffic controller, who returned from South Africa in 2006, because of missing 'home' and the availability of employment, valued being closer to family again. In 2011, he moved to the Middle East with his wife and two young children in order to earn income to meet their mortgage payments (rural\#30). In response to a lack of suitable employment and income, in the area of return, a construction worker (rural\#11) and a managerial employee (spouse of rural\#16) commuted weekly to Scotland and England, respectively, whilst their families remained in Ireland. Younger returnees who had spent shorter periods of time abroad and returned out of family obligation, on the termination of work permits and, or, the availability of employment also experienced tensions relating to the reality that influenced emigration initially, notably in terms of reduced incomes. Their social circle was also reduced through emigration. A number migrated again, using the experience and transnational links that they had established.

\section{Conclusions}

The migration of young working age people from rural areas involves substantial losses of human and social capital (Jentch and Shucksmith, 2004). Their return contributes human, social and economic benefits (Stockdale, 2006; Dustmann et al., 2011). A rural idyllic imaginary that includes aspects of landscape, a more relaxed pace of life and close contact with family in a community environment, features among the factors that influence return and further research is recommended on its role (Stockdale et al., 2013; Haartsen 
and Thissen, 2014). This article was designed to contribute to better understanding of the factors that influence rural return migration by seeking to capture key features of the economic migrant experience from departure, living in a city environment, to return and post-return, using Irish evidence. The sample is relatively small but it includes rich qualitative information relating to the rural migrant life-course. Males outnumber females in the sample but information is provided on family return which includes a spouse and a child or children. Unemployment and constraints on career and personal fulfilment in a rural area of origin emerge as causes for out-migration in the late teens and early twenties, as noted by Stockdale (2006). The advantages of city life are appreciated on arrival, particularly access to employment, higher incomes and superior services and the transition from the area of origin may be facilitated by social and, or, work contact with compatriots. Tensions arise, however, during the reality of adapting to life in a major city, from the larger scale of the place, a sense of anomie in an unfamiliar environment and the loss of close contact with family and friends (Ahmed, 1999). Regret for a loss of features of a rural idyll emerged unprompted from some of the narratives.

Reuniting with family and friends was a major reason for return and became possible when employment opportunities improved in Ireland. Urban life was also re-evaluated at certain stages in the life-course and, notably, in the context of marriage, the birth of a child or children attending school, following Ní Laoire (2007). References to the countryside being a better and safer environment for children and proximity to family suggest that migrants wished their children to grow up in contact with remembered positive features of rural society and proximity to relatives. Help with childcare from grandparents may have been anticipated, although not stated specifically. For those motivated by recapturing a remembered rural idyll, being part of a familiar social field and a peaceful countryside were attained but the reality of rural residence, notably poor service provision, compared unfavourably with city living. Places had changed also as a result of housing development and new residential immigration. Tensions were therefore present between expectations and reality. Most families readapted but some spouses commuted weekly to Britain, for employment and income reasons, to support their families who remained in Ireland. Returnees who were influenced more by obligations to parents, the termination of a work permit or improvements in the Irish economy, than by an idyllic imaginary, recaptured features of 'home' in terms of proximity to family and friends. They experienced tensions relating to employment and income, poor services, the loss of privacy associated with moving back to live with parents, and the emigration of friends. Some of them migrated again using the transnational links that they had established and some returned again.

Out-migration from rural areas is inevitable for many younger people because of the limited availability of higher education, training and desired employment opportunities within commuting distance, and a desire for personal fulfilment (Haartsen and Thissen, 2014). Depopulation, social and 
economic decline are continuing features of some rural areas in Western Europe. Unless wider scale abandonment is to be accepted, measures are required to retain larger numbers of younger people, following completion of higher education or training and to attract others back, as part of the pursuit of the 'good countryside' (Shucksmith, 2018). The reported research illustrates clearly that many overseas emigrants, who were the focus of this paper, retain close links with their family and friends whilst absent and some begin to re-value more idyllic features of their areas of origin, particularly when they consider the upbringing of their children. If economic and employment circumstances permit, they will consider returning to the area of origin. Such returnees may recapture the social idyll that they seek but tensions arise, particularly from poor levels of provision of everyday services. In the case of other returnees who may have spent shorter periods of absence and whose return may be involuntary, reuniting with family and friends is important but an idyllic rural imaginary does not appear to compensate for negative features of rurality. Some of them will migrate again although, possibly, return at a later stage.

The retention of working age populations and the attraction of emigrants back are objectives of rural development policies in many countries (Shucksmith, 2018). As a contribution to policy in Ireland, the results illustrate that access to employment is necessary to facilitate return for most emigrants. So also is improved access to basic transport and other services to provide an acceptable quality of life for them. The motivations and requirements of different groups of returnees to the countryside differ, however, and these differences need to be recognised. Features of a remembered idyll may compensate for the reality of rural life for some returnees but not for others who may migrate again using their transnational knowledge and links.

\section{Acknowledgements}

The assistance of the student interviewees is acknowledged as is that of Dr Stephen Galvin who collated the students' data entries. The most helpful comments of two anonymous referees and the editors are also acknowledged gratefully.

\section{Bibliographical references}

Ahmed, Sara (1999). "Home and away: narratives of migration and estrangement". International Journal of Cultural Studies, 2 (3), 329-347. <https://doi.org/10.1177/136787799900200303>

ARnetT, Jeffrey J. (2000). "Emerging adulthood: a theory of development from the late teens through the twenties". American Psychologist, 55 (5), 469-480. <http://dx.doi.org/10.1037/0003-066X.55.5.469>

Barcus, Holly R. and Brunn, Stanley D. (2010). "Place elasticity: exploring a new conceptualisation of mobility and place attachment in rural America". Geografiska Annaler: Series B, Human Geography, 92 (4), 281-295.

<https://doi.org/10.1111/j.1468-0467.2010.00353.x> 
Barrett, Alan and Mosca, Irene (2013). "Social isolation, loneliness and return migration: evidence from older Irish adults". Journal of Ethnic and Migration Studies, 39 (10), 1659-1677. <https://doi.org/10.1080/1369183X.2013.833694>

Boyle, Paul and Halfacree, Keith (1998). Migration into Rural Areas. Chichester: Wiley and Sons.

Castles, Stephen; de Haas, Hein and Miller, Mark J. (2014, $5^{\text {th }}$ ed.). The Age of Migration: International Population Movements in the Modern World. Basingstoke: Palgrave Macmillan.

Cawley, Mary (2015). "International return migration and rural sustainability: Irish evidence". Carpathian Journal of Earth and Environmental Sciences, 10 (3), 15-24. <http://www.ubm.ro/sites/CJEES/viewIssue.php?issueId=30>

Cawley, Mary and Galvin, Stephen (2016). "Irish migration and return: continuities and changes over time”. Irish Geography, 49 (1), 11-27. <http://dx.doi.org/10.2014/igj.v49il.643>

Christiannse, Suzan and Haartsen, Tialda (2017). "The influence of symbolic and emotional meanings of rural facilities on reactions to closure: the case of the village supermarket". Journal of Rural Studies, 54, 326-336. <http://dx.doi.org/10.1016/j.jrurstud.2017.07.005>

Cloke, Paul (ed.) (2003). Country Visions. Harlow, Essex: Prentice Hall.

Conway, Denis and Potter, Robert B. (2006). "Caribbean transnational return migrants as agents of change". Geography Compass, 1 (1), 1-21. <https://doi.org/10.1111/j.1749-8198.2006.00001.x>

De Bree, June; Davids, Tine and de HaAs, Hein (2010). "Post-return experiences and transnational belonging of return migrants: a Dutch-Moroccan case study". Global Networks, 10 (4), 489-509. <https://doi.org/10.1111/j.1471-0374.2010.00299.x>

Droogleever Fortuijn, Joos and van der Meer, Marieke (2006). "Gender and voluntary work in late adulthood in rural communities in the Netherlands". GeoJournal, 65, 381-392. <https://doi.org/10.1007/s10708-006-0029-6>

Dustmann, Christian; Fadlon, Itzik and Weiss, Yoram (2011). "Return migration, human capital accumulation and the brain drain". Journal of Development Economics, 95 (1), 58-68. $<$ https://doi.org/10.1016/j.jdeveco.2010.04.006>

Eurostat. <http://ec.europa.eu/eurostat/statistics-explained/index.php/Glossary> [consulted: July 27, 2018].

Farrell, Maura; Mahon, Marie and McDonagh, John (2012). "The rural as a return migration destination". European Countryside, 4 (1), 31-44.

Fielding, Tony (1992). "Migration and culture". In: Champion, Tony and Fielding, Tony (eds.). Migration Processes and Patterns: Vol. 1 Research Progress and Prospects. London: Belhaven, 201-212.

Glynn, Irial; Kelly, Tomás and MacÉInrí, Piaras (2013). Irish Emigration in an Age of Austerity. Cork: Emigré, University College Cork.

GMELCH, George (1980). "Return migration". Annual Review of Anthropology, 9, 135-159. <https:/www.annualreviews.org/doi/pdf/10.1146/annurev.an.09.100180.001031>

Granovetter, Mark (1973). "The strength of weak ties”. American Journal of Socio$\log y, 78$ (6), 1360-1380. <https://doi.org/10.1086/225469> 
Gustafson, Per (2001a). "Meanings of place: everyday experience and theoretical conceptualisations". Journal of Environmental Psychology, 21 (1), 5-16. <https://doi.org/10.1006/jevp.2000.0185>

- (2001b). "Roots and routes: exploring the relationship between place attachment and mobility". Environment and Behaviour, 33 (5), 667-686. <https://doi.org/10.1177/00139160121973188>

Haartsen, Tialda and Thissen, Frans (2014). "The success-failure dichotomy revisited: young adults' motives to return to their rural home region". Children's Geographies, 12 (1), 87-101. <http://dx.doi.org/10.1080/14733285.2013.850848>

Halfacree, Keith H. (1993). "Locality and social representation: space, discourse and alternative definitions of the rural". Journal of Rural Studies, 9, 23-37. <https://doi.org/10.1016/0743-0167(93)90003-3>

- (2012). "Heterolocal identities? Counter-urbanisation, second homes, and rural consumption in the era of mobilities". Population, Space and Place, 18, 209-224. $<$ https://doi.org/10.1002/psp.665>

Hay, Robert (1998). "Sense of place in developmental context". Journal of Environmental Psychology, 18, 5-29. <https://doi.org/10.1006/jevp.1997.0060>

Jentch, Birgit and Shucksmith, Mark (eds.) (2004). Young People in Rural Areas in Europe. Aldershot: Ashgate.

MacLaughlin, Jim (1994). The Emigrant Nursery and the World Economy. Cork: Cork University Press.

Matthews, Hugh; Taylor, Mark; Sherwood, Kenneth; Tucker, Faith and Limb, Melanie (2000). "Growing-up in the countryside: children and the rural idyll". Journal of Rural Studies, 16, 141-153. <https://doi.org/10.1016/S0743-0167(99)00059-5>

McHugh Power, Joanna E.; Hannigan, Caoimhe; Carney, Síle and Lawlor, Brian A. (2017). "Exploring the meaning of loneliness among socially isolated older adults in rural Ireland: a qualitative investigation". Qualitative Research in Psychology, 14 (4), 394-414. <https://doi.org/10.1080/14780887.2017.1329363>

Morse, Cheryl (2017). "The emotional geographies of return migration to Vermont". Emotion, Space and Society, 25, 14-21. <https://doi.org/10.1016/j.emospa.2017.09.007>

Morse, Cheryl and Mudgett, Jill (2017). "Longing for landscape: homesickness and place attachment among rural out-migrants in the $19^{\text {th }}$ and $21^{\text {st }}$ centuries". Journal of Rural Studies, 50, 95-103. <https://doi.org/10.1016/j.jrurstud.2017.01.002>

Newbold, K. Bruce (2001). "Counting migrants and migrations: comparing lifetime and fixed-interval return and onward migration”. Economic Geography, 77 (1), 23-40. <https://doi.org/10.1111/j.1944-8287.2001.tb00154.x>

Ní LAOIRE, Caitríona (2007). “The 'green green grass of home’? Return migration to rural Ireland”. Journal of Rural Studies, 23 (3), 332-344. <https://doi.org/10.1016/j.jrurstud.2007.01.005>

OECD (Organisation for Economic Co-operation and Development) (2010). Strategies to Improve Rural Service Delivery. Paris: OECD. 
PAsCuAl-De-SAns, Àngels (2004). "Sense of place and migration histories: idiotopy and idiotope". Area, 36 (4), 348-357. <https://doi.org/10.1111/j.0004-0894.2004.00236.x>

Ploeg, Jan Douwe van der (2012, ebook). The New Peasantries: Struggles for Autonomy and Sustainability in an Era of Empires and Globalization. London: Routledge.

Punch, Adrian and Finneran, Catherine (1999). "The demographic and socio-economic characteristics of migrants, 1986-1996". Journal of the Statistical and Social Inquiry Society of Ireland, 28 (1), 213-263. <http://hdl.handle.net/2262/2678>

Ralph, David (2014). “Equally at home on Beacon Hill and Hill 16?' Transnational identities among Irish-born return migrants from the United States". Global Networks, 14 (4), 477-494. $<$ https://doi.org/10.1111/glob.12046>

Relph, Edward (1976). Place and Placelessness. London: Pion.

Rogers, Andrei; Raquillet, Richard and Castro, Luis J. (1978). "Model migration schedules and their applications". Environment and Planning A, 10, 475-502. $<$ https://doi.org/10.1068/a100475>

RyE, Jonathan (2006). "Rural youths' images of the rural". Journal of Rural Studies, 22 (4), 409-421. <https://doi.org/10.1016/j.jrurstud.2006.01.005>

SALDAŇA, Johnny (2013). The Coding Manual for Qualitative Researchers. London: Sage.

Schmallegger, Doris and Carson, Dean (2010). "Is tourism just another staple? A new perspective on tourism in remote regions". Current Issues in Tourism, 13 (3), 201-221. <https://doi.org/10.1080/13683500903359152>

Shucksmith, Mark (2018). "Re-imagining the rural: from rural idyll to good countryside". Journal of Rural Studies, 59, 163-172. <https://doi.org/10.1016/j.jrurstud.2016.07.019>

SJAASTAD, Larry A. (1962). "The costs and returns of human migration”. The Journal of Political Economy, 70 (5ii), 80-93. <https://www.jstor.org/stable/1829105>

Stockdale, Aileen (2006). "Migration: pre-requisite for rural economic regeneration?" Journal of Rural Studies, 22 (3), 354-366. <https://doi.org/10.1016/j.jrurstud.2005.11.001>

Stockdale, Aileen; MacLeod, Marsaili and Philip, Lorna (2013). "Connected life courses: influences on and experiences of 'midlife' migration to rural areas". Рориlation, Space and Place, 19 (3), 239-257. <https://doi.org/10.1002/psp.1709>

Thissen, Frans; Droogleever Fortuijn, Joos; Strijker, Dirk and Haartsen, Tialda (2010). "Migration intentions of rural youth in the Westhoek, Flanders Belgium and the Veenkoloniën, The Netherlands". Journal of Rural Studies, 26, 432-436. <https://doi.org/10.1016/j.jrurstud.2010.05.001>

Tönnies, Ferdinand (1887/1963). Community and society (Gemeinschaft und Gesellschaft, translated and edited by Charles E. Loomis). New York: Harper and Row.

WALter, Bronwyn (1980). "Time-space patterns of second wave Irish immigration into British towns". Transactions of the Institute of British Geographers New Series, 5 (3), 297-317. <https://doi.org/10.2307/621844>

Williams, Raymond (1973). The City and the Countryside. Oxford: Oxford University Press. Woods, Michael (2011). Rural. London: Routledge. 